Irrigation and Drainage Performance ASSESSMENT

Practical Guidelines 
This book is the result of long-term cooperation between the members of the ICID Working Group on Performance Assessment of Irrigation and Drainage.

The members of the Working Group were:

Dr M.G. Bos, Chairman (The Netherlands)

Dr Fatma Abdel-Rahman Attia (Egypt)

Dr M.N. Bhutta (Pakistan)

Professor N. Borin (Italy)

Dr R.A.L. Brito (Brazil)

Dr M.A. Burton (UK)

Mr J. Chambouleyron (Argentina)

Mr Lee Chang Chi (Taiwan RoC)

M.J.F. Metzger (Canada)

Dr D.J. Molden (USA)

Dr B. Molle (France)

Mr J.A. Ortiz F.-Urrutia (Spain)

Mr J. Plantey (France)

Dr Sang Hyun Park (South Korea)

Dr T. Watanabe (Japan)

Mr G.J. Wright (Australia)

Dr J. Yang (P.R. China)

Mr I. Makin for IWMI (Sri Lanka)

The authors can be reached at the following institutions:

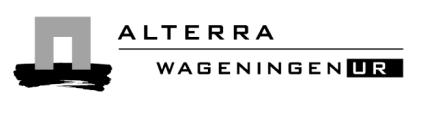

International Institute for Land Reclamation and Improvement Alterra-ILRI,

PO Box 47, 6700 AA Wageningen,

The Netherlands

www.ilri.nl

ITAD Water Ltd, 12 English Business Park,

English Close, Hove,

West Sussex BN3 7ET, UK

www.itad.com

International Water Management Institute, PO Box 2075, Colombo, Sri Lanka www.iwmi.cgiar.org 


\title{
IRRIGATION AND DRAINAGE Performance Assessment Practical Guidelines
}

\section{M.G. Bos}

International Institute for Land Reclamation and Improvement Wageningen, The Netherlands

\author{
M.A. Burton \\ ITAD Water \\ Hove, UK \\ and
}

\section{D.J. Molden}

International Water Management Institute Colombo, Sri Lanka

CABI Publishing 


\section{CABI Publishing is a division of CAB International}

CABI Publishing

CAB International

Wallingford

Oxfordshire OX10 8DE

UK

Tel: +44 (0)1491 832111

Fax: +44 (0)1491 833508

E-mail: cabi@cabi.org

Website: www.cabi-publishing.org
CABI Publishing

875 Massachusetts Avenue

7th Floor

Cambridge, MA 02139

USA

Tel: +1 6173954056

Fax: +1 6173546875

E-mail: cabi-nao@cabi.org

(C) M.G. Bos, M.A. Burton and D.J. Molden 2005. All rights reserved. No part of this publication may be reproduced in any form or by any means, electronically, mechanically, by photocopying, recording or otherwise, without the prior permission of the copyright owners.

A catalogue record for this book is available from the British Library, London, UK.

\section{Library of Congress Cataloging-in-Publication Data}

Bos, Marinus Gijsberthus, 1943-

Irrigation and drainage performance assessment : practical guidelines / M.G. Bos,

M.A. Burton, and D.J. Molden.

$$
\text { p. } \mathrm{cm} \text {. }
$$

Includes bibliographical references and index.

ISBN 0-85199-967-0 (alk. paper)

1. Irrigation--Evaluation. 2. Irrigation--Management. 3. Drainage--Evaluation.

I. Burton, M. A. S. II. Molden, D. J. III. Title.

TC805.B683 2004

631.5'87--dc22

ISBN 0851999670

Typeset by Columns Design Ltd, Reading

Printed and bound in the UK by Cromwell Press, Trowbridge 


\section{Contents}

Preface

vii

Chapter 1 Introduction

Chapter 2 Framework for Performance Assessment

Chapter 3 Performance Indicators for Irrigation and Drainage

Chapter 4 Operational and Strategic Performance Assessment

Chapter 5 Diagnosing Irrigation Performance

Chapter 6 Data Management for Performance Assessment

Appendix 1

Appendix 2

Index 


\section{Abstract}

Performance assessment of irrigation and drainage is the systematic observation, documentation and interpretation of the management of an irrigation and drainage system, with the objective of ensuring that the input of resources, operational schedules, intended outputs and required actions proceed as planned. Following an introduction on this concept in Chapter 1, a framework on performance assessment is presented in Chapter 2. Chapter 3 then defines and discusses 23 recommended indicators covering the water balance, the environment and the economic aspects of the region. The method by which the indicators are used for operational and strategic performance assessment is discussed in Chapter 4, while the diagnostic use of the concept is presented in Chapter 5. The ultimate purpose of performance assessment is to achieve an efficient and effective project performance by providing relevant feedback to the project management at all levels. All related aspects of data management and communication with water users are illustrated in Chapter 6. 


\section{Preface}

The purpose of this handbook is to draw together the knowledge that has been gained in irrigation and drainage performance assessment over the last 10-15 years. Much has been written, and it is time to put down guidelines to enable practitioners to apply the processes and procedures that have been developed. The handbook aims to provide a generic framework for performance assessment with guidance on how to design and carry out performance assessment programmes.

The handbook is aimed at a variety of irrigation and drainage professionals, including scheme managers, researchers and consultants. Performance assessment is an essential management task. If the use of water for irrigation is to be improved, then we must understand current levels of performance and identify measures for improvement.

The primary advantage of 'performance-oriented water management' is that a water management strategy has to be formulated in consultation with all stakeholders. This 'agreed strategy' then forms the foundation of the operational rules of the irrigation and drainage project. In addition, performance assessment has the following major advantages:

- The use and consumption of water by different user groups (farming, drinking water, industrial water, ecosystems, etc.) can be quantified and weighted with respect to each other and the actual water use policy.

- Time series of performance indicators that are plotted with respect to the related critical value or benchmark value show the time when these values will be reached. This then defines the period that is available for management actions.

- The use of various resources (land, water, funds, knowledge, etc.) for the production of food and fibre are quantified and compared with target values. Negative effects can be diagnosed. 
- The impact of management actions on the use of resources and on crop yield can be monitored with respect to target values.

- The systematic presentation of the actual performance of the irrigation and/or drainage project improves communication between stakeholders.

Members of the ICID (International Commission on Irrigation and Drainage) Working Group on Performance Assessment of Irrigation and Drainage have field-tested these guidelines through several case studies. These studies showed that the range of potential applications for these guidelines is unlimited. Acknowledgements are due to all members of the Working Group for their contributions and comments, in particular Jacques Plantey, Bruno Molle and Ricardo Brito, and the USCID Working Group on Irrigation Performance Assessment.

We hope that this book will contribute to the effective management of one of the earth's most widely needed, used and wasted natural resources: water.

Marinus G. Bos Wageningen, The Netherlands

Martin A. Burton Hove, UK

David J. Molden Colombo, Sri Lanka 